\title{
MATHEMATICAL MODELLING OF HYDRODYNAMICS AND WATER QUALITY IN A TROPICAL RESERVOIR, NORTHEAST BRAZIL
}

\author{
ARAUJO, M..$^{*}$; COSTA, M.F. ${ }^{2}$; AURELIANO, J.T. ${ }^{3}$ \& SILVA, M.A. ${ }^{1}$ \\ ${ }^{1}$ Laboratory of Physical and Coastal Oceanography (LOFEC) \\ ${ }^{2}$ Laboratory of Ecology and Management of Estuarine \& Coastal Ecosystems \\ Department of Oceanography - DOCEAN/UFPE \\ Av. Arquitetura, s/n, Campus UFPE, Recife-PE, Brazil, CEP: 50740-550 \\ ${ }^{3}$ Pernambuco Environmental Agency - CPRH \\ Rua Santana, 367, Casa Forte, Recife-PE, Brazil, CEP. 52060-460
}

\begin{abstract}
Araujo, M.; Costa, M.F.; Aureliano, J.T. \& Silva, M.A. 2008. Mathematical modelling of hydrodynamics and water quality in a tropical reservoir, Northeast Brazil. Braz. J. Aquat. Sci. Technol. 12(1):19-30. ISSN 18087035. The Pirapama system in Pernambuco, Northeast Brazil, is one of the last major sources of adequate water supply in the state. A reservoir was constructed to store water for domestic, agricultural and industrial use. However, the formation of the reservoir pool flooded the marginal vegetation, starting an organic matter mineralization process, which resulted in eutrophication of the waters and depletion of dissolved oxygen concentrations, reaching anoxic conditions near the reservoir bed. This water body is also impacted by upstream inputs of domestic sewage, agricultural run-off and effluents from sugar-cane mills and distilleries. This work applied a one-dimensional vertical approach (CE-QUAL$\mathrm{R} 1$ ) in order to simulate the formation of the reservoir pool, analysing the different operational alternatives. Eutrophication, anoxia and stratification potentials were studied. Water quality data obtained during 17 months are used to adjust the model rates and parameters. After model calibration-validation, hypothetical operational scenarios were simulated, taking into account different ways for water pumping (outtake elevations) and for discharging outflow excess (spillways or bottom outlet). Strong anoxic conditions (DO concentrations of less than $1.0 \mathrm{mg} \cdot \mathrm{L}^{-1}$ ), associated to high eutrophication levels (high $\mathrm{PO}_{4}$ and Chlorophyll-a concentrations), were found in all simulated scenarios. Regarding water quality conditions in the reservoir, the use of bottom outlet for reservoir water releases presented better results than the other operational alternatives, since it makes possible releasing anoxic waters from the deepest layers of the reservoir pool. However, in these conditions, the water quality downstream from the reservoir was severely compromised.
\end{abstract}

Keywords: Reservoir dynamics, Eutrophication, Pirapama River Basin, CE-QUAL-R1 model.

\section{INTRODUCTION}

Due to intense and prolonged drought periods the population of Recife Metropolitan Area was forced to endure periods of severe water rationing. The lower portion of the Pirapama hydrographic basin is considered to be one of the last major water sources available in Pernambuco State. The State Government determined the construction of a reservoir located at Pirapama River in order to increase water availability for the urban populations, agriculture and industry. The Pirapama River Dam was planned to reduce, or possibly to match, the demand in the region. The dam has been operational since the end of 2001.

The mineralization of the flooded vegetation of the riverbed and strong upstream agricultural fertilizing activities was already expected after the formation of

*Corresponding author: moa@ufpe.br. Fax: +55.81.21268225. CNPq fellow the reservoir pool and an eutrophication process started. Due to stratification (thermal, chemical or hydraulic) the deepest waters of the reservoir stagnated, providing the conditions for the formation of anoxic regions due to bacterial activity. Bacterial action can produce gases such as sulphide and methane, which are potentially harmful and can cause corrosion of the dam structure, hydraulic pipelines and water supply machinery. Consequently, operational staff and the environment may be put at risk (Heide, 1982). To reduce these potentially damaging conditions bottom outlets have been considered several times in reservoir design and construction (Hernandez et al., 1989; Araujo et al., 1990; Wu et al., 1996).

In this paper the mathematical model CE-QUALR1 (USACE/WES, 1986) is used to infer water quality changes in the Pirapama pool during reservoir filling and stabilization phases. The influence of different operational scenarios is also examined. In the first part of the study model results are compared to physico-chemical and 
water quality field data as a way for adjusting model rates and parameters. After that, two hypothetical cases were simulated. These new situations explore the effects of removing pool outflow excess through two different dam outlet structures (elevation levels) over reservoir water quality.

\section{Water quality modeling and reservoir management}

During the last three decades considerable effort has been expended in developing mathematical models to predict eutrophic states of natural and man-made lakes as functions of nutrient inputs (Jørgensen, 1986; Jørgensen \& Bendoricchio, 2001). The works of Chen \& Orlob (1972) and Di Toro et al. (1971) represent important pioneer work in this field of eutrophication models. While the most of the first water quality models were rather research oriented, a lot of new modeling tools were quickly developed intending to be directed mainly at practical application as for environmental management. Nyholm (1978), for example, developed a model for phytoplankton growth and phosphorus and nitrogen cycling in eutrophic, shallow lakes. This model has been used to simulate a 1-year trophic cycle at 12 different lakes in Denmark, as part of two Danish water quality survey projects undertaken by the Water Quality Institute, Denmark. Jørgensen et al. (1978) validated an eutrophycation model using data from both Lyngby Lake and Glumsø Lake. Their model was calibrated on the basis of data obtained from measurements of Lyngby Lake during 1952-1958. After validation, the Jørgensen's model was used to simulate the changes of Lyngby Lake during the period 1959-1975.

Schnoor \& O'Connors (1980) also used an eutrophication model to investigate the trophic evolution of a short detention time reservoir at Central Texas, U.S.A. (Lake Lyndon B. Johnson), and a long detention time Great Lake (Lake Ontario). These authors applied this approach as a management tool for 81 phosphorus limited lakes of the U. S. National Eutrophication Survey (NES).

A two-dimensional, laterally averaged, finitedifference hydrodynamic and water transport quality model was applied to DeGray Lake, Arkansas, U.S.A. by Martin (1988). In this case, field data from two separated years were used to calibrate and verify the model. Spatial and temporal variations in dissolved oxygen concentrations and other water quality variables were successfully predicted throughout the stratification cycles.

The CE-QUAL-R1 model was evaluated using data collected at a small eutrophic reservoir near Spring Valley, Wisconsin, U.S.A. (Wlosinski \& Collins, 1985). Weekly or biweekly data collected in 1981 and 1982 were used as a basis for calibration and validation simulations. Over 3200 comparisons of measured versus predicted values, for 20 different variables, were made for each year. Results pointed out that the model is able to predict temporal evolution of the water quality state-variables at the reservoir.

Always on the basis of observation data, calculation, and mathematical modelling, Dubnyak \& Timchenko (2000) examined the role of the current regimes, wind-waves and turbulent mixing processes over the water quality in the Dnieper reservoirs, Ukraine. The authors discussed the possibilities of hydrodynamics management in these man-made lakes.

In 2000-2001 the World Bank supported a modelling project to study the possible impact on the Lake Malawi/Nyasa/Niassa (eastern Africa) water quality, due to actions performed at the watershed level (Lam et al., 2001; Leon et al., 2003). In this project, physical and bio-chemical processes models in the lake were integrated, resulting on a set of tools able to analyse the impact on the lake due to changes in upstream nutrient loadings. The effects of different agricultural practices and deforestation impacts over the lake water quality were examined.

More recently, Parinet et al. (2004) used a Principal Component Analysis technique in some eutrophic lakes systems of Ivory Coast, western Africa. Results stressed that the relationships between analytical state-variables in ecological models can accurately generate better system descriptors than state-variables themselves. They also suggest that very simple parameters (i.e., pH, conductivity UV absorbance at $254 \mathrm{~nm}$ and permaganate index for raw water) can be successfully used for reservoirs water quality management.

Tundisi (1990) identifies and describes some basic characteristics of tropical and subtropical reservoirs in South America and the necessary modelling effort. The author argues that the size, volume and dimension of these large artificial ecosystems justify the implementation of several methodological approaches useful for modelling, including oceanographic techniques and intensive use of satellite images. By the same time it is stressed that it is necessary to consider river recovery capacity, water uses and flow regime requirements in the region downstream. In the same year, Araujo et al. (1990) used the CE-QUAL-R1 model to analyze the usefulness and feasibility of hydraulic structures in allowing management procedures for reservoir water-quality control. The example was a study of the feasibility of a bottom outlet in altering water-quality tendencies of an Amazonian hydroelectric powerplant project - Cachoeira Porteira Reservoir, Brazil. The simulations involved four different hypotheses, with consideration of different flow rates through a bottom outlet. The alterations to reservoir waterquality tendencies were analyzed, emphasizing the 
intensity of stratification, eutrophication, and anoxic conditions caused by the flooding of natural vegetation. Results suggest that careful consideration of the outlet positions should be included in the future design and operation of reservoirs.

A similar approach was performed by Wu et al. (1996), which investigate the effect of Ta-Chi Reservoir (Taiwan) operation on water quality using a box-series model. In this case, different reservoir operation policies were simulated to address the possibility of maintaining water quality through proper operation. Simulations results indicate that an appropriate operation rule can improve outlet water quality by releasing water from a certain depth in the reservoir.

\section{MATERIAL AND METHODS}

Pirapama River Basin Basin, Pernambuco State,

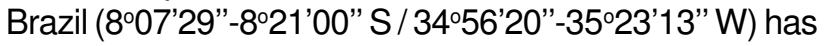
a $600 \mathrm{~km}^{2}$ surface area (Figure 1). The riverhead is $450 \mathrm{~m}$ above MSL, and the river course runs about $80 \mathrm{~km}$ until it reaches the Atlantic Ocean, where it shares the estuary with Jaboatão River (Araujo et al., 1999).

Climate is typically tropical, wet and warm, and the mean temperature is $26 \pm 2.8^{\circ} \mathrm{C}$. Mean annual precipitation and evaporation are $1.5 \mathrm{~m}$ and $1.2 \mathrm{~m}$, respectively. The region's hydrology characterized by two well-defined periods: a dry season (September March, monthly precipitation $\leq 0.06 \mathrm{~m}$ and evaporation exceeds precipitation) and a rainy season (March September, when the hydrological balance is positive). The basin receives large domestic, agricultural and industrial untreated, or partially treated, discharges. The lower regions are surrounded by relatively well preserved mangrove forests. The main features of Pirapama reservoir are presented in Table 1.

CE-QUAL-R1 (Corps of Engineers, QUAL series model for 1-D Reservoirs) is a mathematical model by Waterways Experiment Station, from the U.S. Army Corps of Engineers (Wlosinski \& Collins 1985; USACE/ WES, 1986). Its structure is characterized by a onedimensional vertical approach applied to reservoirs, conceptualised as a sequence of horizontal well-mixed layers which thickness depend on the inflow-outflow water balance (Figure 2). It can be used to help improve water quality in the reservoir pool and in released downstream flows.

Water temperature is mainly affected by the shape of the reservoir, inflows and outflows, short- and long-wave radiation at water surface, net heat transfer through air-water interface, diffusion, convective mixing and heat decay along the water body. Biological processes include photosynthesis, respiration, ingestion, mortality and decomposition. The model uses two main sub-routines: one for the selective allocation of inflows, computed accordingly for vertical density profiles, and another related to water withdrawal through dam structures (ports and/or free weirs) (Figure 2).

Vertical transport of thermal energy and materials is taken into account by the model through entrainment and turbulent diffusion. First, the entrainment is a transport process that sharpens gradients and determines the depth of the upper mixed region and the onset of stratification. This process is calculated from the turbulent kinetic energy influx generated by wind shear and convective mixing. Second, the turbulent diffusion is a transport process that reduces gradients

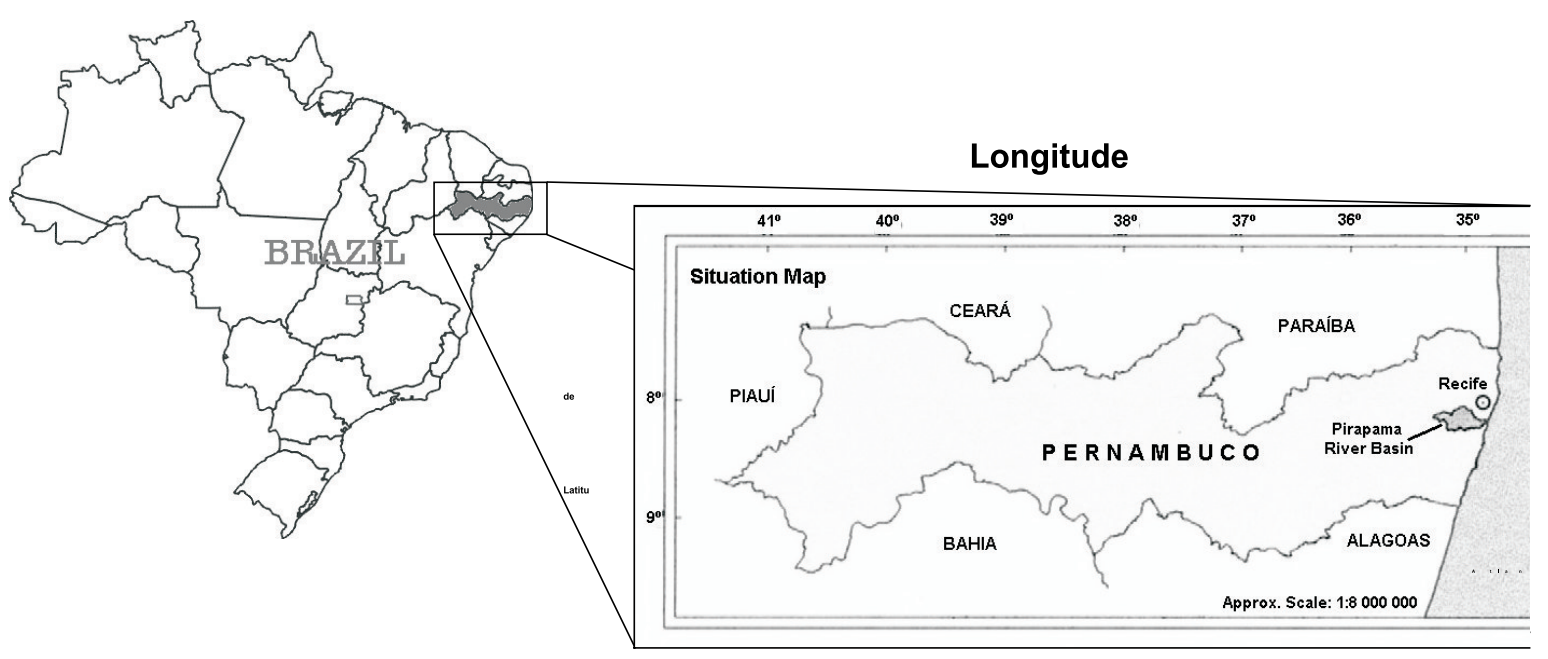

Figure 1 - Pirapama River Dam (and the former course of Pirapama River). Sampling stations for upstream boundary conditions (PP2-20) and Calibration-Validation scenarios (PP2-50) are indicated. 
Table 1 - Technical features of the Pirapama reservoir.

\begin{tabular}{ll}
\hline \multicolumn{1}{c}{ Feature } & \multicolumn{1}{c}{ Value } \\
\hline Mean bottom elevation (MSL) & $23 \mathrm{~m}$ \\
Long term mean tributary & $10.5 \mathrm{~m}^{3} \cdot \mathrm{s}^{-1}$ \\
Surface area (elevation $45.7 \mathrm{~m})$ & $6,610.0 \times 10^{3} \mathrm{~m}^{2}$ \\
Cumulated volume (elevation $45.7 \mathrm{~m})$ & $60,973.0 \times 10^{3} \mathrm{~m}^{3}$ \\
& Upper outtake $: 39.1 \mathrm{~m}$ \\
Water pumping structures & Lower outtake $: 28.5 \mathrm{~m}$ \\
& Spillways : $45.7 \mathrm{~m}$ \\
Dam outlet structures & Bottom outlet : $26.0 \mathrm{~m}$ \\
\hline \hline
\end{tabular}

and is calculated using a turbulent diffusion coefficient that is dependent on wind speed, inflow and outflow magnitudes, and density stratification.

Mathematically, the conservation of mass in CEQUAL-R1 model is written as

$$
\frac{\partial(V C)}{\partial t}=\sum_{k} Q_{\mathbb{N}} \cdot C_{\mathbb{N}}-Q_{\text {OUT }} \cdot C+\frac{\partial\left(A D \frac{\partial C}{\partial z}\right)}{\partial z} \Delta Z+F-S
$$

where:

$\mathrm{k}=$ index for tributaries

$\mathrm{V}=$ layer volume $\left(\mathrm{m}^{3}\right)$

$\mathrm{C}=$ material concentration $\left(\mathrm{g} \cdot \mathrm{m}^{-3}\right)$

$\mathrm{Q}_{\mathrm{IN}}=$ layer inflow $\left(\mathrm{m}^{3} \cdot \mathrm{s}^{-1}\right)$

$\mathrm{C}_{\text {IN }}=$ inflow concentration $\left(\mathrm{g} \cdot \mathrm{m}^{-3}\right)$

$\mathrm{Q}_{\text {OUT }}=$ layer outflow $\left(\mathrm{m}^{3} \cdot \mathrm{s}^{-1}\right)$

$D=$ diffusion coefficient $\left(\mathrm{m}^{2} \cdot \mathrm{s}^{-1}\right)$

$A=$ horizontal surface area of the layer $\left(\mathrm{m}^{2}\right)$

$\mathrm{DZ}=$ layer thickness $(\mathrm{m})$

$\mathrm{F}=$ Source terms of material $\left(\mathrm{g} \cdot \mathrm{s}^{-1}\right)$

$\mathrm{S}=$ Sinking terms of material $\left(\mathrm{g} \cdot \mathrm{s}^{-1}\right)$

$\mathrm{t}=$ time $(\mathrm{s})$

$\mathrm{z}=$ layer elevation $(\mathrm{m})$

The dynamical features of the model allow it to generate temporal depictions of vertical concentration profiles of different variables. State variables considered in this study are temperature, dissolved oxygen, one group of algae (Chlorophyll-a), detritus, dissolved organic matter, orthophosphate, ammonia, (nitrite + nitrate), carbon, zooplankton, $\mathrm{pH}$, carbon dioxide and feacal coliforms.

The physical representation of the reservoir was also considered to be adequate using this tool. A power function was used to calculate the Pirapama reservoir area as a function of elevation from MSL. A correlation coefficient of 0.97 was obtained using sixty elevation points in the study area. Determination of outflow vertical distribution required a description of the geometrical characteristics of the water inlets and spillways in

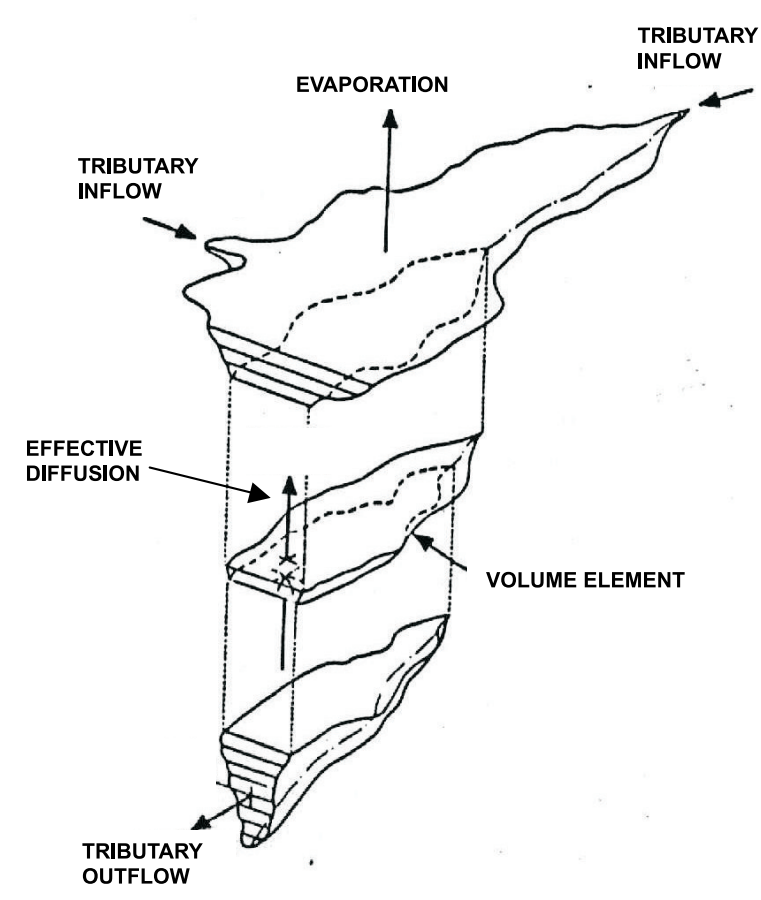

Figure 2 - Geometric representation of a reservoir and mass transport mechanisms in the CE-QUAL-R1 model.

addition to the relationship between transversal widths and their respective water levels. The reservoir dam is designed to have control-gate weirs, water supply pipelines, and a bottom outlet.

A 64-year monthly flow series was analysed to obtain a long-term mean flow used to establish the upstream boundary conditions for all simulated scenarios (Table 2). A 4-year limnological and water quality field data were collected from 2 sampling stations. The sampling station PP2-20 was used as upstream boundary condition (Table 3 ) and station PP2-50, located at the deeper near-dam portion, gave the initial filling condition and the database for model calibration and validation (Fig. 1). Daily averages of the meteorological data were obtained from two meteorological stations in the region (IPA/LAMEPE, 2000). The recent 2-part papers of Arhonditsis \& Brett $(2005 a, b)$ provide a more detailed description of the methodology used in model calibration and validation.

Initial estimation of rates and constants used in the model were based on the literature (Bowie et al., 1985; USACE/WES, 1986; Jørgensen et al., 1991; Jørgensen \& Bendoricchio, 2001) and final values were determined from the best adjustment of model results to measurements (see model calibration in next section). Total simulation time was 36 months, beginning with the filling at the initial month of the mean hydrological cycle - March $1^{\text {st }}, 2001$. Field and simulations data indicate that the reservoir became operational about 4.5 
Table 2 - Simulation scenarios of the Pirapama reservoir.

\begin{tabular}{ccc}
\hline \hline Scenario & $\begin{array}{c}\text { Water outtake } \\
\text { (elevation, MSL) }\end{array}$ & $\begin{array}{c}\text { Outflow excess } \\
\text { (elevation, MSL) }\end{array}$ \\
\hline Calibration & Upper outlet $(39.1 \mathrm{~m})$ & Spillways $(45.7 \mathrm{~m})$ \\
Forecast simulation 1 - FS1 & Lower outlet $(28.5 \mathrm{~m})$ & Spillways $(45.7 \mathrm{~m})$ \\
Forecast simulation 2 - FS2 & Upper outlet $(39.1 \mathrm{~m})$ & Bottom outlet $(23.0 \mathrm{~m})$ \\
\hline
\end{tabular}

months later, when the water level was at $45.7 \mathrm{~m}$. A24hour computational time step and a mean vertical layer thickness of $2.0 \mathrm{~m}$ were adopted.

The reservoir filling program in all simulations was based on the following steps:

- Filling reservoir procedures starting from the first day of rainy season (March $1^{\text {st }}, 2001$ );

- Granting a minimal, regularized, $1.2 \mathrm{~m}^{3} . \mathrm{s}^{-1}$ downstream flow along the whole simulation period - reservoir filling included;

-Pumping of $1.8 \mathrm{~m}^{3} . \mathrm{s}^{-1}$ in 2001 and 2002, starting when water level reached the elevation of the spillways ( 45.7 $\mathrm{m})$;

-Pumping of $3.6 \mathrm{~m}^{3} \cdot \mathrm{s}^{-1}$, from January 2003 onwards

\section{RESULTS AND DISCUSSION}

Simulation results were analysed considering the variations reservoir water quality. The selection of the necessary parameters aimed to allow a quantitative identification of the main mechanisms influencing the reservoir water quality.

Experience filling other tropical reservoirs, where the effects of anthropic actions were studied, indicates the prevalence of certain processes which affect the water quality control mechanisms (Baxter et al., 1965; Heide, 1982; Lewis Jr., 1987; Hernandez et al., 1989; Jørgensen \& Araujo, 1988; Araujo, 1991; Araujo et al., 1990; Tundisi, 1990; Salas \& Martino, 1991). Special attention was paid to the following processes:

- Stratification potential - Thermal energy distribution profiles along water column.

- Eutrophication potential - acceleration of primary production enhanced by nutrient intake from autochthonous and allochthonous organic matter mineralization;

- Anoxic potential - dissolved oxygen depletion associated to the degradation of organic matter that enters the reservoir.

\section{Model adjustment to Pirapama reservoir (Calibration- Validation scenarios)}

Temporal variation on vertical profiles of Temperature - $\mathrm{T}\left({ }^{\circ} \mathrm{C}\right), \mathrm{pH}$, Dissolved Oxygen - DO (mg. $\left.\mathrm{L}^{-1}\right)$, Biogeochemical Oxygen Demand - $\mathrm{BOD}_{5,20}$ (mg. $\left.\mathrm{L}^{-1}\right)$, and Orthophosphate $-\mathrm{PO}_{4}\left(\mathrm{mg} \cdot \mathrm{L}^{-1}\right)$ are
Table 3 - Available month-averaged boundary conditions used in simulations (sampling station PP2-20, Fig. 1). Minimum, Maximum and Mean values are presented, with its corresponding periods of occurrence (Months).

\begin{tabular}{|c|c|c|c|}
\hline Variable & Min. (Month) & Max. (Month) & Mean (Month) $\left(^{*}\right)$ \\
\hline Flow $\left(m^{3} \cdot s^{-1}\right)$ & 5.3 (January) & 19.1 (July) & 10.8 (March) \\
\hline $\mathrm{T}\left({ }^{\circ} \mathrm{C}\right)$ & 25.4 (August) & 29.6 (December) & 2.7 (October) \\
\hline $\mathrm{DO}\left(\mathrm{mg} \cdot \mathrm{L}^{-1}\right)$ & 3.2 (May) & 6.8 (November) & 4.8 (September) \\
\hline $\mathrm{BOD}_{5,20}\left(\mathrm{mg} \cdot \mathrm{L}^{-1}\right)$ & 2.1 (August) & 32.4 (April) & 7.2 (March) \\
\hline $\mathrm{PO}_{4}\left(\mathrm{mg} \cdot \mathrm{L}^{-1}\right)$ & 0.08 (January) & 0.26 (July) & 0.16 (April) \\
\hline $\mathrm{NH}_{4}\left(\mathrm{mg} \cdot \mathrm{L}^{-1}\right)$ & 0.20 (January) & 0.79 (July) & 0.37 (April) \\
\hline $\mathrm{NO}_{2}+\mathrm{NO}_{3}\left(\mathrm{mg} \cdot \mathrm{L}^{-1}\right)$ & 0.05 (October) & 0.23 (July) & 0.13 (April) \\
\hline Feacal coliforms (No./100 mL) & 1,300 (February) & 41,020 (October) & 13,870 (May) \\
\hline $\mathrm{pH}$ & 6.1 (May) & 7.5 (November) & 6.8 (September) \\
\hline $\operatorname{TDS}\left(\mathrm{mg} \mathrm{L}^{-1}\right)$ & 71.7 (July) & 129.1 (June) & 97.4 (February) \\
\hline
\end{tabular}

illustrated in Figures $3 a$ and $3 b$. These profiles are presented in five 17-month sequences (from August, 2001 to December, 2002) showing the differences from field data and final model outputs for real conditions (Calibration-Validation scenarios). These two periods together represent about half of the total simulation time. In Figures $3 \mathrm{a}$ and $3 \mathrm{~b}$ the horizontal axis corresponds to state variables values and the vertical axis to water column depth. Field data are not plotted in some of these graphics when they could not be measured and/ or analyzed. Furthermore, no field information about nitrogen species, phytoplankton and zooplankton were available.

Figure 3 a represents the Calibration period (from August, 2001 to March, 2002) involving the rainy and dry seasons. Once the model parameters and rates were adjusted and fixed, the model Validation was performed by the comparison between numerical outputs and the second dataset (from April, 2002 to December, 2002; also involving rainy and dry seasons, Figure 3b).

Previous sensitivity analysis involving the CEQUAL-R1 modelling of tropical reservoirs pointed out five most influential parameters acting over the pool water quality (Araujo et al., 1990; Araujo, 1991). These are: photosynthesis rate of the algal compartment (AMU); stoichiometric equivalent between organic matter and carbon (BIOC); stoichiometric equivalent between organic matter and nitrogen (BION); stoichiometric equivalent between organic matter and phosphorus (BIOP); and maximum decay rate of organic matter (DOMK). Each of the these parameters were assigned ranges and statistical distribution based on published literature values (Bowie et al., 1985; USACE/WES, 1986; Jørgensen et al., 1991; Jørgensen \& Bendoricchio, 2001) (Table 4).

The strategy employed for calibration was to perform two hundred stochastic simulations using Monte Carlo method. This permitted the five parameters to be 
Table 4 - Description and calibration values used in the simulation of the Pirapama reservoir, Brazil.

\begin{tabular}{|c|c|c|c|}
\hline $\begin{array}{l}\text { Variable } \\
\text { (Units) }\end{array}$ & Description & $\begin{array}{l}\text { Literature } \\
\text { range }\left(^{*}\right)\end{array}$ & $\begin{array}{l}\text { Simulation } \\
\text { Value }\end{array}$ \\
\hline AMU $\left(\right.$ day $\left.^{-1}\right)$ & $\begin{array}{l}\text { Photosynthesis rate of the algal } \\
\text { compartment }\end{array}$ & $0.1-11.5$ & 1.7 \\
\hline $\mathrm{BIOC}(-)$ & $\begin{array}{l}\text { Stoichiometric equivalent between } \\
\text { organic matter and carbon }\end{array}$ & $0.4-0.6$ & 0.45 \\
\hline BION (-) & $\begin{array}{l}\text { Stoichiometric equivalent between } \\
\text { organic matter and nitrogen }\end{array}$ & $0.0005-0.09$ & 0.015 \\
\hline $\mathrm{BIOP}(-)$ & $\begin{array}{l}\text { Stoichiometric equivalent between } \\
\text { organic matter and phosphorus }\end{array}$ & $0.0001-0.02$ & 0.0003 \\
\hline DOMK $\left(\right.$ day $\left.^{-1}\right)$ & Maximum decay rate of organic matter & $0.004-0.64$ & 0.08 \\
\hline
\end{tabular}

varied randomly according to predetermined statistical distribution (Normal distribution) and allowed simulations to be repeated so that response statistics could be compiled. The best set of parameter values (see Table 4) was obtained when the minimum value of the objective function $\sigma=\sqrt{\frac{1}{N} \sum_{1}^{N} \frac{\left(x_{t}^{i}-x_{o}^{i}\right)}{x_{m}^{i}}}$ (computed after each Monte Carlo simulation) was achieved (Jørgensen \& Bendoricchio, 2001). In this formulation $\mathrm{N}$ is the number of state variables, $X_{t}^{\prime}$ is the calculated value of the $\mathrm{i}^{\text {th }}$ state variable, $X_{o}$ is the corresponding measured value and $X_{m}$ is the average, observed value of the $i^{\text {th }}$ state variable.

Vertical profiles of temperature indicate that Pirapama reservoir is a weakly-stratified pool. Larger differences between surface and bottom temperatures are observed during the dry season (September to March in both years), although they are not significant.

Measured and simulated concentrations of $\mathrm{PO}_{4}$ in Figures $3 a$ and $3 b$ indicate high levels of mineral enrichment of the reservoir waters. Vertical distributions show higher values (more than $0.2 \mathrm{mg}^{-\mathrm{L}^{-1}}$ ) near the bottom, probably associated to settling of $\mathrm{PO}_{4}$ adsorbed to suspended solids, organic matter degradation and anoxic sediment releases. Lower orthophosphate values near the lake surface observed in field data and simulation are a consequence of algae assimilation.

Near the water surface and inside of the wellmixed upper reservoir layers, high values of DO are observed. These important concentrations found in the upper lake waters are also associated to phytoplankton oxygen production during photosynthesis process. Dissolved oxygen (DO) profiles in Figure $3 \mathrm{a}$ and $3 \mathrm{~b}$, coupled to BOD distributions indicate that strong bacterial activity takes place in the Pirapama reservoir. Higher values of BOD are observed in the lower part of the water column. These high concentrations of organic matter are associated to strong anoxic conditions (DO less than $1.0 \mathrm{mg} \cdot \mathrm{L}^{-1}$ ) below $10 \mathrm{~m}$ depth, verified in field data and model results.

\section{Stratification potential}

Trends in the thermal stratification of the reservoir were evaluated from the time evolution of the thermocline elevation (elevation of the maximum temperature gradient) and their correspondent maximum thermal gradient values - MTG (Figures 4a to 4c). The charts suggest that this reservoir will not suffer a persistent stratification. This was observed for all studied scenarios. Temperature amplitudes between the top of the metalimnion and bottom limits showed maximum values $<1^{\circ} \mathrm{C} . \mathrm{m}^{-1}$ for most of the simulations.

Observing vertical profiles and thermocline evolution, it is noticeable that maximum gradients were periodically surpassed in the Calibration and FS1 simulations. The magnitude of the thermal stratification depends on each scenario being analysed. When using the $28.5 \mathrm{~m}$ outtake it seemed to be less favourable to intense stratification cycles than FS1 scenario.

Scenario FS2 (Figure 4c) differed from the other situations: after the onset of the reservoir filling process an intensive mixing of the water column is observed in the following months. Less important temperature gradients and deeper thermocline elevations are then registered after considering bottom outlet.

\section{Eutrophication potential}

An excessive algal proliferation in all scenarios could be observed, especially during the rainy season (Figure 5). At the third and fourth simulation months, large algal concentrations were observed at the euphotic zone in all scenarios. This period is characterised by a strong trend of thermal stratification and a significant reduction of Secchi disk readings. At this time values of up to $17 \mathrm{mg} . \mathrm{L}^{-1}$ of chlorophyll-a (Chl-a) were observed for the superficial layers of the reservoir for all study cases associated with the onset of filling procedures. After that period $\mathrm{Chl}$-a concentration reached peaks of different magnitudes depending on the operational variants adopted. Curves for Calibration and forecast scenario FS1 in Figure 5 point out three peaks of phytoplankton production, associated to the months when larger organic and inorganic loads were also observed (March to June, 2001; March to July, 2002; and March to August, 2003). However, the other forecast scenario FS2 has presented a different behaviour regarding eutrophication; the removal of waters via bottom outlets promotes a significant reduction of Chla levels from the twelfth month after initiating filling procedures.

In all scenarios, the months of maximum phytoplankton production were associated to a sharp reduction in Secchi readings (down to $0.20-0.30 \mathrm{~m}$ ). 
This was also observed in situ at other similar reservoir systems (e.g. Tapacurá reservoir, COMPESA, 2000), especially when intense algal proliferation was registered.

Temporal evolution of total phosphorus is presented in Figure 6. In all scenarios, high levels of dissolved phosphorus were observed at the water column, largely exceeding the $100 \mathrm{mg} \cdot \mathrm{L}^{-1}$ classical limit proposed by Vollenweider (1968) for temperate lakes, and the specific value of $119 \mathrm{mg} . \mathrm{L}^{-1}$ more recently suggested for tropical reservoirs (Salas \& Martino, 1991). The shapes of the curves have a periodicity of 12 months, emphasizing the strong influence of the typical tropical seasonality, regardless of which operational option is considered.

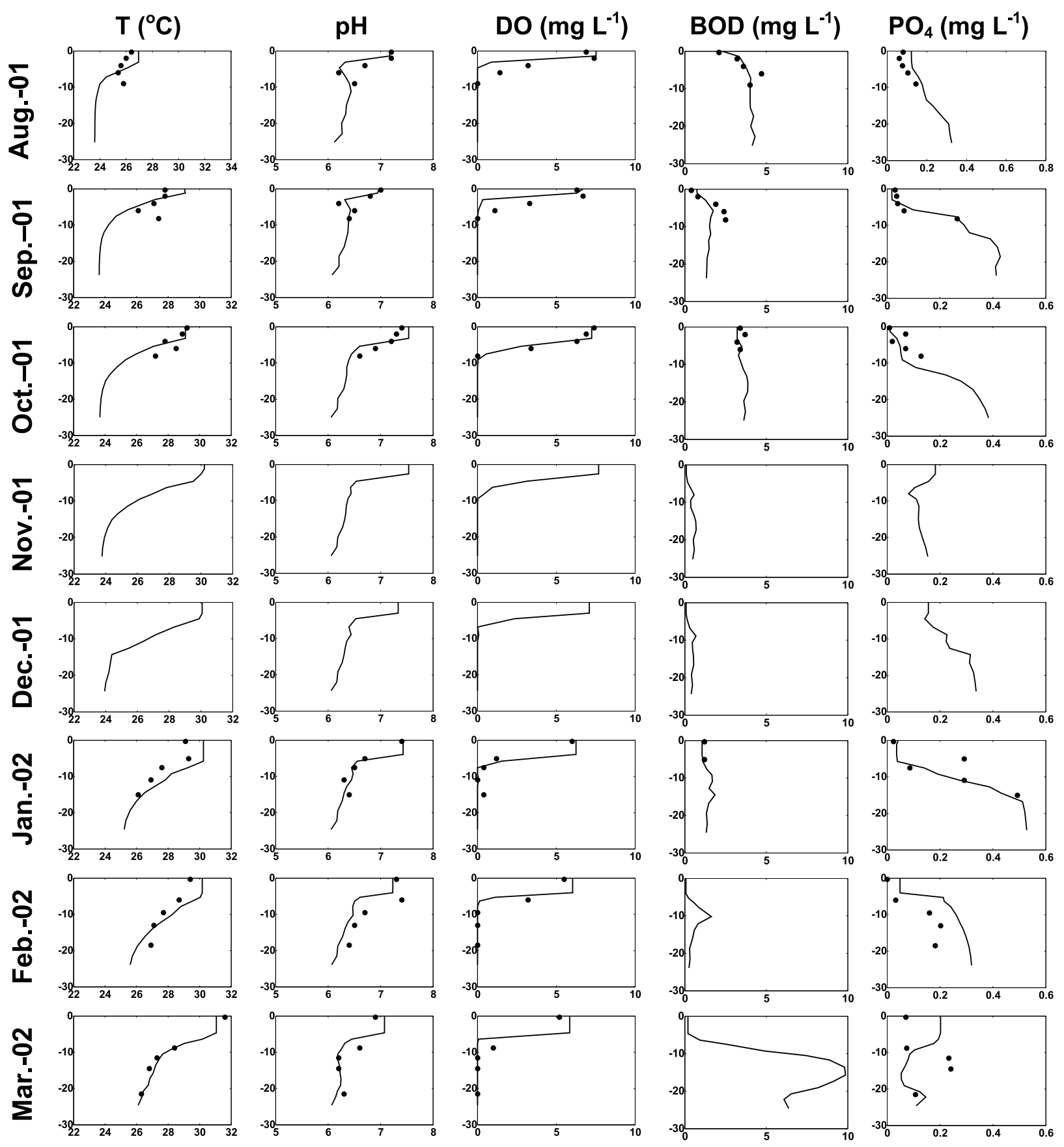

Figure 3a - Comparison between field experimental data 2002). 


\section{Anoxic potential}

The anoxic zone is defined here as the region where DO concentrations are below $1.0 \mathrm{mg} . \mathrm{L}^{-1}$. It is also associated to the hydrothermal behaviour of the reservoir since the thermocline forms a physical barrier to oxygen vertical diffusion.

The large amounts of organic matter originated from regions upstream the dam is likely to cause

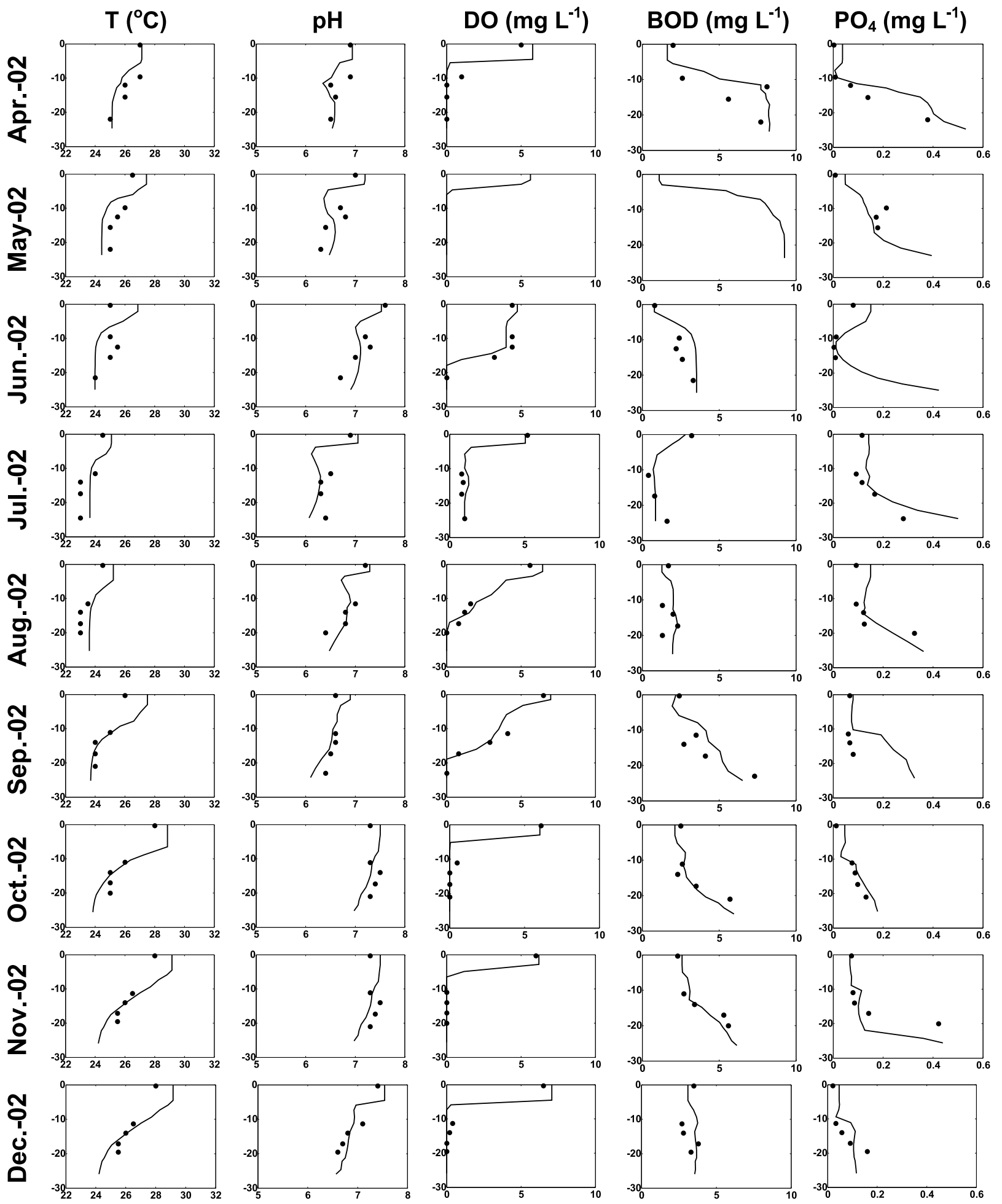

Figure $3 b$ - Comparison between field experimental data 2002). 
elevated BOD concentrations in the water column. Figure $7 \mathrm{a}$ and $7 \mathrm{~b}$ show a continuous anoxic condition, practically during the entire simulation period, for Calibration and FS1 cases. DO vertical concentration profiles for this scenario show typical clinograde profiles (Figures $3 a$ and $3 b$ ). Oxyclines are characterised by higher values at the surface and eutrophication zone, followed by thick anoxic deeper layers. In several scenarios a DO super-saturation at the surface was observed, invariably connected to oxygen production due to photosynthesis from algal blooms. This indicates high eutrophication levels when the dam is operational (24 months after the start of the filling process), and after that. A similar scenario is observed from simulation FS1 (deep outtake from water pumping) because of the better water quality of the layers next to this outlet.
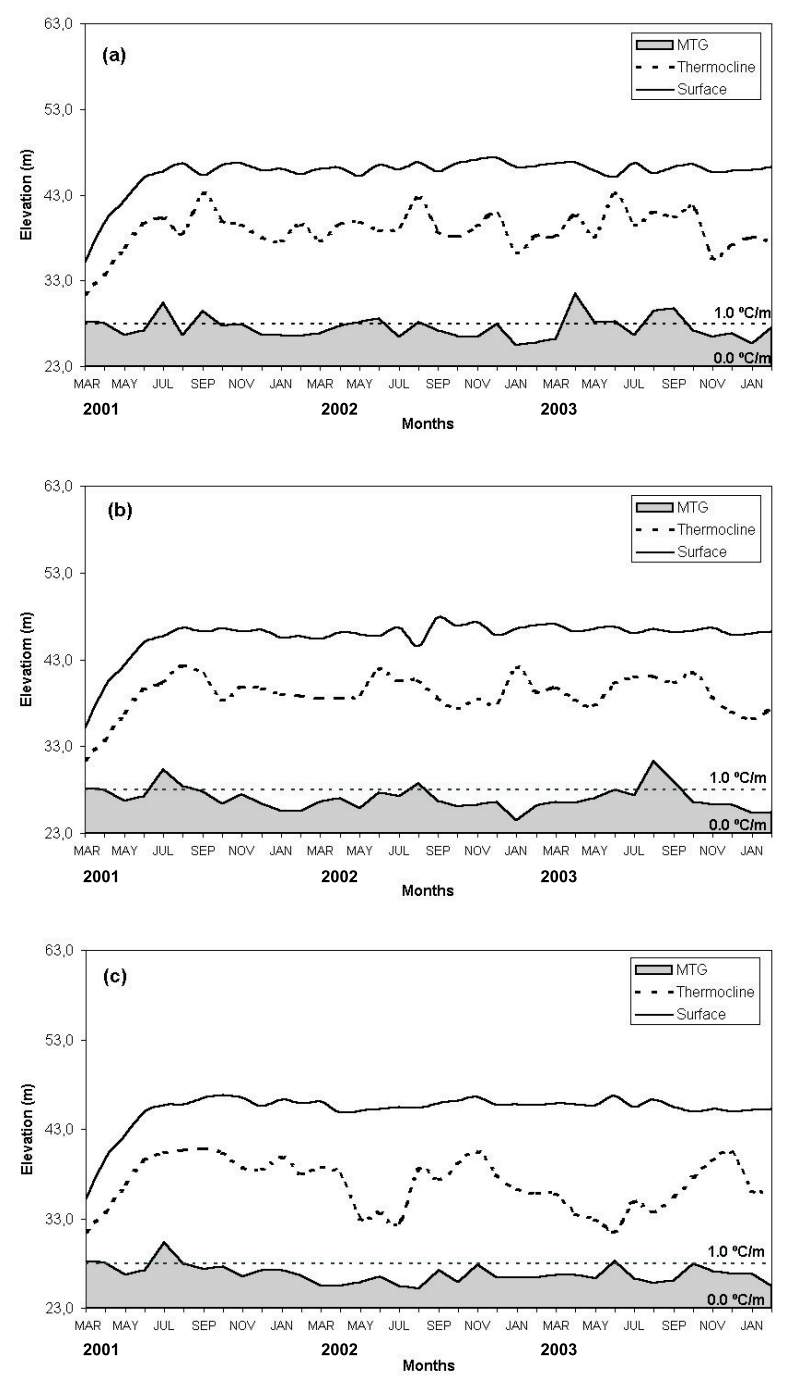

Figure 4 - Temporal evolution of the Maximum Temperature Gradient (MTG) and thermocline depth obtained in numerical simulations. (a) Calibration scenario, (b) Forecast scenario FS1, and (c) Forecast scenario FS2.
Scenario FS2 represents the less critical situation (Figure 7c), since the water column tends to be oxygenated in a typical rainy season from the second year of simulation onwards. Such condition comes from the effective use of bottom outlets, which has made possible releasing anoxic waters from the deepest layers of the reservoir pool. These dam operation techniques, for minimizing water quality impacts, are continuously more employed in practice to remove stagnated anoxic layers and to improve water column vertical mixing via advection and turbulent diffusion physical mechanisms (Araujo et al., 1990; Wu et al., 1996). However, despite of all benefits, the use of bottom outlets has proven contraproducent for the downstream regions, especially just after the dam.

Besides the severe limitations to biological diversity in the aquatic system, the extreme anoxia, suggested by simulation results, can have other harmful consequences. Under anaerobic conditions, phosphorus will be released from the sediments and transported by physical action to the superficial layers of the reservoir. Field and experimental analyses have confirmed the hypothesis of anoxic sediments as an important source

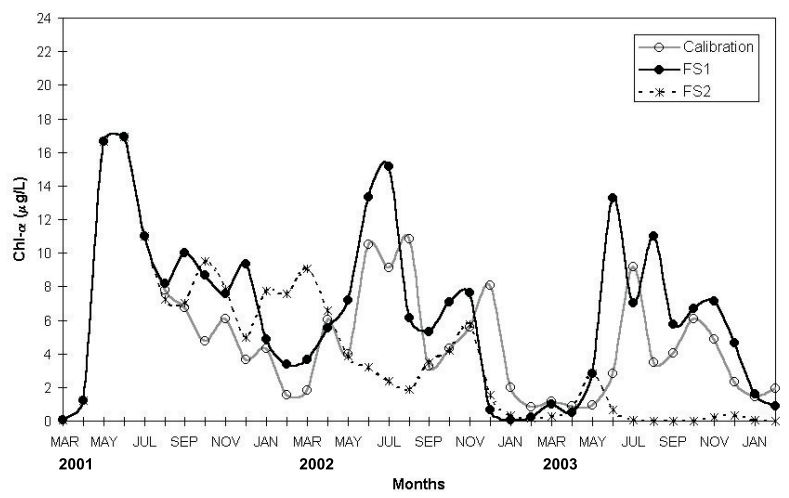

Figure 5 - Temporal evolution of the Chlorophyll-a concentration in euphotic zone obtained in numerical simulations.

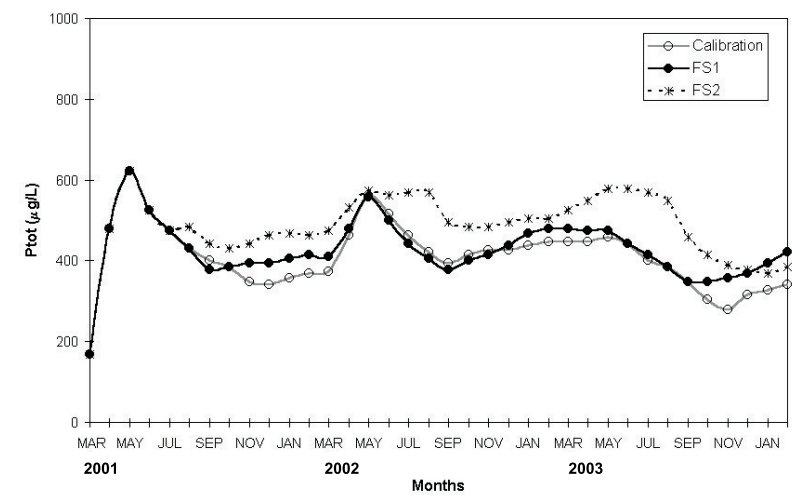

Figure 6 - Temporal evolution of the total Phosphorus concentration obtained in numerical simulations. 
of nutrients for the water column (Baccini, 1985; Schindler, 1985). This mechanism was important for the evolution of the trophic status of reservoirs subjected to high benthic oxygen demands (Chen \& Orlob, 1975; Henderson-Sellers, 1984).

\section{CONCLUSIONS}

In this paper is used a one-dimensional vertical approach in order to evaluate the formation of a reservoir pool in Northeastern part of Brazil. Different dam operational alternatives are investigated. Simulated scenarios indicate that the water quality at Pirapama reservoir is linked to the allochthonous organic and inorganic loads. The system is not capable of recovering
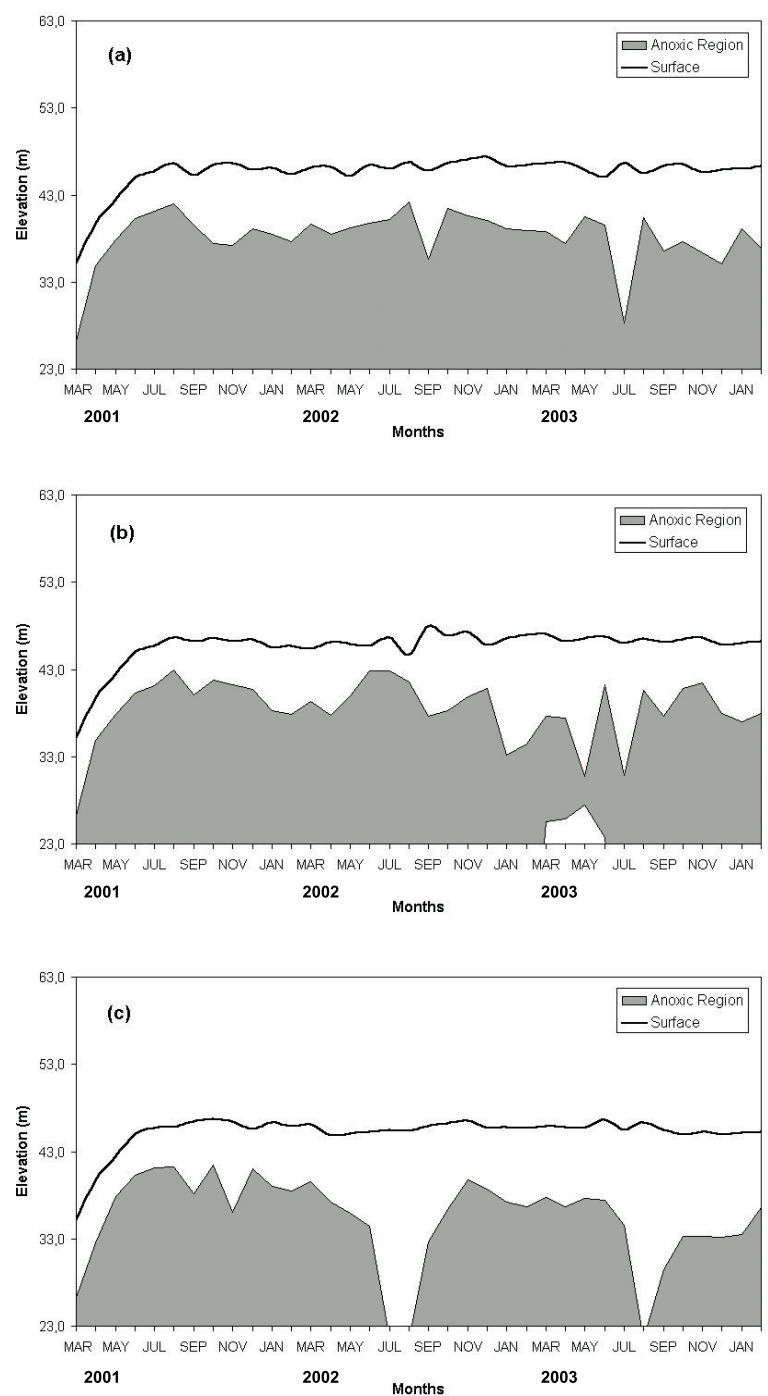

Figure 7 - Temporal evolution of the anoxic layer thickness obtained in numerical simulations. (a) Calibration scenario, (b) Forecast scenario FS1, and (c) Forecast scenario FS2. from the upstream loads by itself. High anoxic and primary production levels were observed during the months of increased upstream flow to the reservoir, which is in agreement with other field experiments performed in similar systems in the region (COMPESA, 2000).

The water outtake option using the deep outlet (simulation FS1), instead of the upper one (real situation used for model calibration), does not bring much advantage to improving water quality in the reservoir. Choosing between these two alternatives must consider sanitary, public health risks and expenses related to water treatment. It should be decided between taking anoxic, hypolimnetic, nutrient-enriched waters or oxygenated, epilimnetic waters, subjected to high concentrations of phytoplancton biomass.

The results also suggest that using bottom outlets in a rational way could be a reliable mechanism to minimize impacts on water quality within the reservoir. The solutions obtained for forecast scenario FS2 show a thermal stratification reduction, allied to an intensive vertical mixing of the water column. This could lead to the oxygenation of its entirety in periods of intense flow through the reservoir. However, regarding water quality standards, the periods of water release by bottom outlets correspond, undoubtedly, to the worse situation for the river water downstream from the dam. Therefore, it is recommended that bottom outlets should be used with care, in very special, programmed occasions, and preferably in dry season.

Actions leading to the reduction and control of organic and inorganic loads carried towards the reservoir must be encouraged. The results of this work highlight the dependence of water quality standards on allochthonous loads from upstream. It is suggested that additional hydrodynamic and water quality modelling efforts should be employed upstream and downstream from the dam. This procedure will allow quantifying and monitoring the effects of pollution mitigation initiatives on the affluent water quality entering the reservoir. In this case, more detailed mathematical modelling upstream from the reservoir would be necessary to support efficient implementation and management of water quality, which is increasingly more adopted by hydrographical basin management agencies around the world.

\section{ACKNOWLEDGEMENTS}

This study was supported by the Pernambuco State Government, Pernambuco Water and Sewage Company (COMPESA) and Pernambuco Environmental Agency (CPRH). The authors gratefully acknowledge the support and the water quality data provided by COMPESA and CPRH. 


\section{REFERENCES}

Araujo, M. 1991. Modelagem matemática no gerenciamento da qualidade da água em reservatórios. Uma primeira estimativa das futuras tendências na qualidade da água durante as fases de enchimento e estabilização de reservatórios tropicais. O caso da UHE Porteira. Dissertação Mestrado Universidade de São Paulo. Volumes I e II. $231 \mathrm{p}$.

Araujo, M.; Jesus, J.A.O.; Hernandez, J.A.M. \& Branski, J.M. 1990. Mathematical modelling for reservoir water quality management through hydraulics structures. A case study. Ecological Modelling. 52(1):73-85.

Araujo, M.; Medeiros, C. \& Ribeiro, C. 1999. Energy balance and time-scales of mixing and stratification in the Jaboatão estuary, NE-Brazil. Brazilian Journal of Oceanography. 47(2):145-154.

Arhonditsis, G.B. \& Brett, M.T. 2005a. Eutrophication model for Lake Washington (USA): Part II - Model calibration and system dynamics analysis. Ecological Modelling. 187:179-200.

Arhonditsis, G.B. \& Brett, M.T. 2005b. Eutrophication model for Lake Washington (USA): Part I - Model description and sensitivity analysis. Ecological Modelling. 187:140-178.

Baccini, P. 1985. Phosphate interaction at the sedimentwater interface. In: Stumm, W. (ed.) Chemical processes in lakes. John Wiley and Sons. 189205pp.

Baxter, R. M.; Prosser, M.V.; Talling, J.F. \& Wood, R.B. 1965. Stratification in tropical african lakes at moderate altitudes $(1,500$ to $2000,0 \mathrm{~m})$. Limnology and Oceanography. 10(4):510-520.

Bowie, G.L.; Wills, W.B.; Porcella, D.B.; Campbell, C.L.; Pagenkopf, J.R.; Rupp, G.L.; Johnson, K.M.; Chan, P.W.H.; Gherini, S. \& Chamberlin, C.E. 1985. Rates, constants, and kinetics formulations in surface water quality modelling. U. S. E.P.A. Report no. EPA/600/ 3-85/040, $454 \mathrm{p}$.

Chen, C.W. \& Orlob, G.T. 1972. Ecological simulation for aquatic environments. Office of Water Resources Research OWRR C-2044, U. S. Army Engineer Waterways Experiment Station, The Hydrologic Center, $156 \mathrm{p}$.

Chen, C.W. \& Orlob, G.T. 1975. Ecologic simulation of aquatic environment. In: Patten, B.C. (ed.) Systems analysis and simulation in ecology, Vol. 3. Academic Press 12. 476-588pp.

COMPESA - Companhia Pernambucana de Saneamento 2000. Dados de monitoramento das águas do reservatório de Tapacurá. Gerência de Controle de Qualidade, Divisão de Controle de Laboratórios. Recife, Brasil., 20pp.
Di Toro, D. M.; O'Connors, D. J. \& Thomann, R. V. 1971. A dynamic model of the phytoplankton population in the Sacramento - San Joaquin delta. Advances Chemistry Series. 106:131-180.

Dubnyak, S. \& Timchenko, V. 2000. Ecological role of hydrodynamic processes in the Dnieper reservoirs. Ecological Engineering. 16:181-188.

Heide, J. van der 1982. Filling phase limnology of a manmade lake in the humid tropics. Biologisch Laboratorium, Vrije Universiteit, NE, 428 p.

Henderson-Sellers, B. 1984. Engineering limnology. Pitman Publishers, Inc., $357 \mathrm{p}$.

Hernandez, J.A.M.; Jesus, J.A.O.; Araujo, M. \& Branski, J. M. 1989. Modelagem matemática no gerenciamento da qualidade da água em reservatórios tropicais. Dois casos típicos. Anais do VIII Simpósio Brasileiro de Recursos Hídricos, Associação Brasileira de Recursos Hídricos ABRH.1(1):606-618.

IPA/LAMEPE - Empresa Pernambucana de Pesquisa Agropecuária/Laboratório de Meteorologia e Recursos Hídricos de Pernambuco 2000. Dados meteorológicos da Estação de Vitória, Recife, Brazil. 4 p.

Jørgensen, S.E.; Mejer, H. \& Friis, M. 1978. Examination of a lake model. Ecological Modelling. 4:253-278.

Jørgensen, S.E. 1986. Fundamentals of ecological modelling. Developments in Environmental Modelling 9. Elsevier Sciences Publishers, $389 \mathrm{p}$.

Jørgensen, S.E. \& Araujo, M. 1988. Modelagem ecológica de reservatórios. In: J. G. Tundisi (ed.) Limnologia e Manejo de Represas, Academia de Ciências do Estado de São Paulo 1(2). 395 -402pp.

Jørgensen, S.E.; Nielsen, S.N. \& Jørgensen, L.A. 1991. Handbook of ecological parameters and ecotoxicology. Pergamon Press, Amsterdam. $1264 p$.

Jørgensen, S. E. \& Bendoricchio, G. 2001. Fundamentals of ecological modelling. Developments in Environmental Modelling 21. Elsevier Sciences Publishers, $530 \mathrm{p}$.

Lam, D.C.; Léon, L.F.; Hecky, R.; Bootsma, H. \& McCrimmon, C. 2001. Modelling approach for Lake Malawi/Nyasa/Niassa: integrating climatological, hydrological and limnological data, IDEAL. Advances in Global Research Series, vol. 2. Kluwer Academic Publishers.

Léon, L.F.; Lam, D.C.; McCrimmon, C. \& Swayne, D.A. 2003. Watershed manegement modelling in Malawi: application and technology transfer. Environmental Modelling \& Software. 18:531-539.

Lewis Jr., W.M. 1987. Tropical limnology. Ann. Ver. Ecol. Syst.. 18:159-184. 
Martin, J. L. 1988. Application of two-dimensional water quality model. Journal of Environmental Engineering ASCE. 114(2):317-336.

Nyholm, N. 1978. A simulation model for phytoplankton growth and nutrient cycling in eutrophic, shallow lakes. Ecological Modelling. 4:279-310.

Parinet, B.; Lhote, A. \& Legube, B. 2004. Principal component analysis: an appropriate tool for water quality evaluation and management - application to a tropical lake system. Ecological Modelling. 178(34):295-311.

Salas, H. J. \& Martino, P. 1991. A simplified phosphorus trophic state model for warm-water tropical lakes. Water Research. 25(3):341-350.

Schindler, D.W. 1985. The coupling of elemental cycles by organisms: evidence from whole-lake chemical perturbations. In: Stumm, W. (ed.), Chemical processes in lakes. John Wiley \& Sons. 225-250pp.

Schnoor, J. L. \& O'Connors, D. J. 1980. A steady state eutrophication model for lakes. Water Research. 14(11):1651-1665.
Tundisi, J. G. 1990. Perspectives for ecological modeling of tropical and sub tropical reservoirs in South America. Ecological Modelling. 52(1-2):7-20.

USACE/WES - U. S. Army Corps of Engineers/ Waterways Experiment Station 1986. CE-QUAL-R1: A numerical one-dimensional model of reservoir water quality - User's Manual. Environmental Laboratory, Instruction Report E-82-1, 427 p.

Vollenweider, R.A. 1968. Scientific basis of lake and stream eutrophication, with particular reference to phosphorus and nitrogen as eutrophication factors. Technical Report OECD DAS/DSI/68 27, 182p.

Wlosinski, J.H. \& Collins, C.D. 1985. Evaluation of a water quality model (CE-QUAL-R1) using data from a small Wisconsin reservoir. Ecological Modelling. 29:303-313.

Wu, R.S.; Sue, W.R.; Chen, C.H. \& Liaw, S.L. 1996. Simulation model for investigating effect of reservoir operation on water quality. Environmental Software. 11(1-3):143-150. 